\title{
Modeling traffic barriers crash severity by considering the effect of traffic barrier dimensions
}

\author{
Amirarsalan Mehrara Molan ${ }^{1} \cdot$ Mahdi Rezapour $^{1} \cdot$ Khaled Ksaibati $^{1}$
}

Received: 21 November 2018/Revised: 7 February 2019/Accepted: 25 March 2019/Published online: 10 April 2019

(C) The Author(s) 2019

\begin{abstract}
Traffic barriers are in widespread all around the USA as safety countermeasures for reducing the severity of run-off-road crashes. The effect of traffic barriers' dimension had been ignored in past real-world crash studies due to the considerable cost and time needed for collecting field data. This paper presented two new analytical models to investigate the effect of different variables on the severity of crashes involving traffic barriers, and end treatments. For this reason, a field survey was conducted on over 1.3 million linear feet of traffic barriers (approximately 4,176 miles road) in Wyoming to measure traffic barriers' geometric features like height, length, offset, and slope rate. The collected data included $55 \%$ of all non-interstate roads of Wyoming. Based on results, the crashes involving box beam barriers were less severe than the crashes involved with W-beam or concrete barriers. The traffic barriers with a height between 28 and $31 \mathrm{in}$. were found safer than the traffic barriers shorter than 28 in., while there was no significant difference between the traffic barriers taller than 31 in. to those shorter than 28 in. in terms of crash severity. The end treatments located nearer to the traffic lane had lower crash severity.
\end{abstract}

Amirarsalan Mehrara Molan

amehrara@uwyo.edu

Mahdi Rezapour

mrezapou@uwyo.edu

Khaled Ksaibati

khaled@uwyo.edu

1 Wyoming Technology Transfer Center, Department of Civil \& Architectural Engineering, University of Wyoming, 1000 E. University Avenue, Dept. 3295, Laramie, WY 82071, USA
Keywords Crash severity · Run-off-road crashes · Traffic barriers - End treatments - Traffic barrier dimensions . Real-world crash analysis · Wyoming

\section{Introduction}

Based on statistics, vehicle collision was ranked as the 7th cause of life lost between 2012 and 2014 in the USA [1]. In other words, vehicle crashes annually result in more than 37,000 fatalities in the USA. This rate is equivalent to $\$ 148$ billion based on estimated comprehensive costs of collisions [2]. Run-off-road (ROR) crashes include a considerable portion of the fatal and injury collisions. Between 2014 and 2016, 53\% of the US fatal vehicle crashes were ROR which caused 18,779 fatalities [3]. Traffic barriers are known as one of the countermeasures for reducing the severity of ROR crashes. The main task of traffic barriers in crashes is to redirect the vehicles running off the road to keep them safe in the clear zone. Therefore, designing an appropriate traffic barrier is a key point in reducing crash severity because the traffic barrier should be designed strong enough to control the vehicles in clear zones as well as transferring the minimum reaction forces to driver and passengers for preventing crash fatalities and serious injuries. Traffic barriers were initially designed to avoid the vehicles from running off of the road, while designers were noticing less in terms of the crash severity [4]. Unfortunately, many of the old traffic barrier segments have not been upgraded in accordance with recent design policies due to the substantial cost needed to replace them [4, 5]. From another point of view, roadway speed limit, as a parameter related to crash severity, has been changed considerably over the last four decades. The first national maximum speed limit (NMSL) in the USA was assigned as 
$55 \mathrm{mph}$ in 1974 [6]. Then, the NMSL was raised to $65 \mathrm{mph}$ in 1987. Finally, the National Highway System Designation Act of 1995 repealed the NMSL, and the authority was given to states to set various speed limits [7]. The maximum highest speed limit currently in the USA reaches to $85 \mathrm{mph}$. As another possible concern regarding the severity of crashes involving traffic barriers, the volume of heavy vehicles (like pickup and SUV) is getting increased in the USA. Based on recent statistics, pickup sales in the USA showed an annual growth about 5\% between 2015 and 2017 [8]. These inconsistencies between variables related to crash severity and traffic barrier's design should be a reason for the high rate of fatalities in crashes involving traffic barriers. According to the available crash statistics, traffic barriers are the third most common reason of fixedobject fatalities in the USA [9]. Another study showed that traffic barriers had a direct influence on about 1,000 fatalities and 28,000 injuries that occurred in the USA [10].

In response to the concerns mentioned above, roadside design guide (RDG) [9] has always been upgrading its design policies based on new findings related to crashes involving traffic barriers. For instance, the latest edition of RDG [9] recommends a height of 31 in. (from the ground to the top level of traffic barriers) for the MGS (Midwest Guardrail System) barrier, while the height was already recommended about 27-29 in. This change and the other similar changes in traffic barrier design policy were mostly considered based on the tests done in the studies like NCHRP (National Cooperative Highway Research Program) project no. 350 [11]. However, based on the best knowledge of the authors, no statewide real-world crash analysis has evaluated the traffic barriers' performance considering the effect of the variables related to dimension like the effect of traffic barriers' height.

This paper seeks to investigate the traffic barriers' performance in crashes occurred on non-interstate roads. In addition to considering the variables reported by police officers in crash reports, this research also included the variables related to traffic barriers' hardware (like the type of barrier, end treatment, and the blockouts), traffic barriers' dimension (like height, offset, side slope rate, and postspacing), and roadways' geometry and environment (like shoulder width and the hazardous object) considering a statewide field survey in the study. Finally, we proposed two analytical models for the severity of crashes involving traffic barriers and the crashes involving end treatments. The field survey was conducted on approximately 4,176 miles non-interstate road in Wyoming. Wyoming is a proper testbed for traffic barrier studies to include a variety of variables in the analysis because of having the following advantages:
- Adverse weather situations (snowy and icy roads) in winter and normal condition in summer (mostly dry road condition),

- Mountainous roads with sharp horizontal curves and steep vertical alignments,

- High truck traffic demand (mostly freight trucks) with more than $50 \%$ of the total traffic volume in the roads like US-30. Note that the mean traffic composition in Wyoming's non-interstate roads is $13 \%$ based on the data collected in this study,

- Rural roads with high-speed limits. The speed limit is typically between 75 and $80 \mathrm{mph}$ on interstate roads, and between 65 and $70 \mathrm{mph}$ on state roads,

- Based on previous studies [5, 12], traffic barriers have the first rank of the fixed-object fatal crashes (with a percentage of 38\%) among all the fixed object in Wyoming. Wyoming's roadsides are almost empty of any tree, building, or even utility poles. Therefore, there is a higher risk that the ROR vehicles hit traffic barriers.

The bullet points mentioned above show the condition dominated in Rocky Mountain Region (RMR). Therefore, the results would be recommended to be more practical in the regions similar to RMR with high truck traffic and challenging geometric features.

\section{Background}

Conducting simulated/field crash tests was one of the primary focuses of past studies in traffic barrier evaluations [13-18]. Julin et al. [13] considered simulation modeling and field testing to identify the highest height for the Midwest Guardrail System (MGS) which does not pose any safety risk. According to their results, a maximum height of 36 in. was found safe with no threat of underride for the vehicles in collisions. On the other hand, short-height traffic barriers are also making a safety concern regarding vehicle override. The traffic barriers with a height between 24 and 26 in. could increase the possibility of a vehicle override in W-beam guardrails, while a redirection would be more likely when the traffic barrier height has a range about 27-31 in. [4]. The threat of an override could be even more in the vehicles like trucks with a high center of gravity (CG). Based on FHWA's W-Beam Guardrail Repair [19], the guardrails with a height lower than 24 in. were considered as "no longer reasonably functional." Schmidt et al. [15], and Albuquerque et al. [16] evaluated the length of need of traffic barriers, and it was concluded that a shorter length of need could be considered for the traffic barriers when the sides slope is flat. Hampton and Gabler [17] conducted validated simulation tests to evaluate the effect of the missing posts on W-beam guardrails' 
reaction in crashes. It was identified that removing a post caused an increase of about $25 \%$ and $13 \%$ in maximum deflection and rail tension of the W-beam guardrail, respectively. Tan et al. [18] designed a new guardrail system using a V-profile made of polypropylene to provide a suitable guardrail for motorcyclists. The simulation results showed potential for the new design in terms of absorbing the crash energy.

The before-after analysis was another popular method among researchers for evaluating traffic barriers. Cafiso et al. [20] investigated a crash modification factor (CMF) about 0.78 (22\% reduction in crashes) for upgrading the old traffic barriers. The improvement effect was estimated even more considerably for the ROR crashes showing a CMF equal to 0.67 . Villwock et al. [21] conducted a before-after study to evaluate the effect of installing new median cable barriers on frequency and severity of crashes of eight states in the USA. Overall, the cable barriers resulted in more single-vehicle crashes on wide medians; however, the severity of crashes were decreased in comparison with the before period. The similar results were found in the studies by Chimba et al. [22] and Park et al. [23]. Chimba et al. [22] estimated averagely $82 \%$ and $76 \%$ less fatal and incapacitating injury crashes, respectively, after installing new cable barriers.

There are not many real-world crash studies in terms of investigating the variables that impact the severity of traffic barrier crashes. As one of the first efforts in this field, the analytical model by Holdridge et al. [24] illustrated the contribution of the traffic barrier leading end toward fatal crashes. Using seatbelt was found significantly effective in reducing the severity of crashes hitting traffic barriers and other fixed objects on roadsides. In another study [25], the variables like the belt use, rollover involvement, and vehicle type were recognized as the most effective variables on crash severity when the vehicle hits the traffic barrier end terminal. The research by Zou et al. [26] and Russo and Savolainen [27] were two of the recent studies done on the severity of median traffic barrier crashes in the USA. Both the studies concluded that the motorcycle is the most vulnerable vehicle type in crashes involving traffic barriers. Also, the cable barriers cause less severe crashes in comparison with the other types of traffic barriers. Molan et al. [5] compared the variables affecting the severity of crashes involving traffic barriers in truck and non-truck (light vehicles) crashes. Based on results, it was found that cable barriers are performing safer than the other traffic barriers in non-truck crashes.

As the main contribution of the current research, this paper seeks to add new findings to the literature review by including the variables related to traffic barriers' dimensions in the analysis. Therefore, a clearer view would be provided for transportation agencies to consider safer dimensions for traffic barriers. Also, the results could be useful to find the most hazardous traffic barrier segments.

\section{Methodology}

\subsection{Data collection}

Road environment, traffic, human factors (driver), weather, and traffic barriers were the main components for the analysis in this study. The Critical Analysis Reporting Environment (CARE) package provides comprehensive data regarding the variables related to all these components except the traffic barriers. Therefore, the research team collected the crashes reported between January 2007 and January 2017 in Wyoming using the CARE package, while a traffic barrier inventory was also performed to record the traffic barriers' dimension in Wyoming. In addition to collecting traffic barrier data, some variables related to road characteristics (like shoulder width and the hazardous objects behind the traffic barriers) were also collected during the field survey. The traffic barrier inventory was done from June 2016 to September 2017 as a part of the Wyoming Department of Transportation (WYDOT) guardrail inventory project no. HPR1217 [28]. In this period, over 1.3 million linear feet of traffic was measured along approximately 4,176 miles of roadway. Also, over 7,700 photographs were taken during the field survey. Field crew consisted of two personnel, using mapping grade GPS (global positioning system), laser levels, and other hand measurement devices to measure 2,350 traffic barrier locations primarily located in districts 2,3 , and 5 of Wyoming. The collected data include $55 \%$ of the total 7,563 miles roadways of Wyoming. This study considered the non-interstate roads. In other words, State, FAP (Federal Aid Primary), FAS (Federal Aid Secondary), and FAU (Federal Aid Urban) roads were the classifications collected during the field survey. Figure 1 shows the roads with traffic barriers inventoried for this study. Note that the roads highlighted in green show the roads with traffic barrier inventoried, while the red roads were not included in the study. As a limitation in this study, it is possible that some traffic barrier configurations were changed over the period from 2007 to 2017, while the traffic barrier inventory was conducted in 2016-2017. However, as the authors checked this with WYDOT, it is expected that the portion of the traffic barrier segments replaced or upgraded during 2007-2017 would be negligible.

\subsection{Statistical analysis method}

Similar to past studies [5, 24, 26, 27, 29], data analysis was conducted using an ordinal logistic regression. Three 


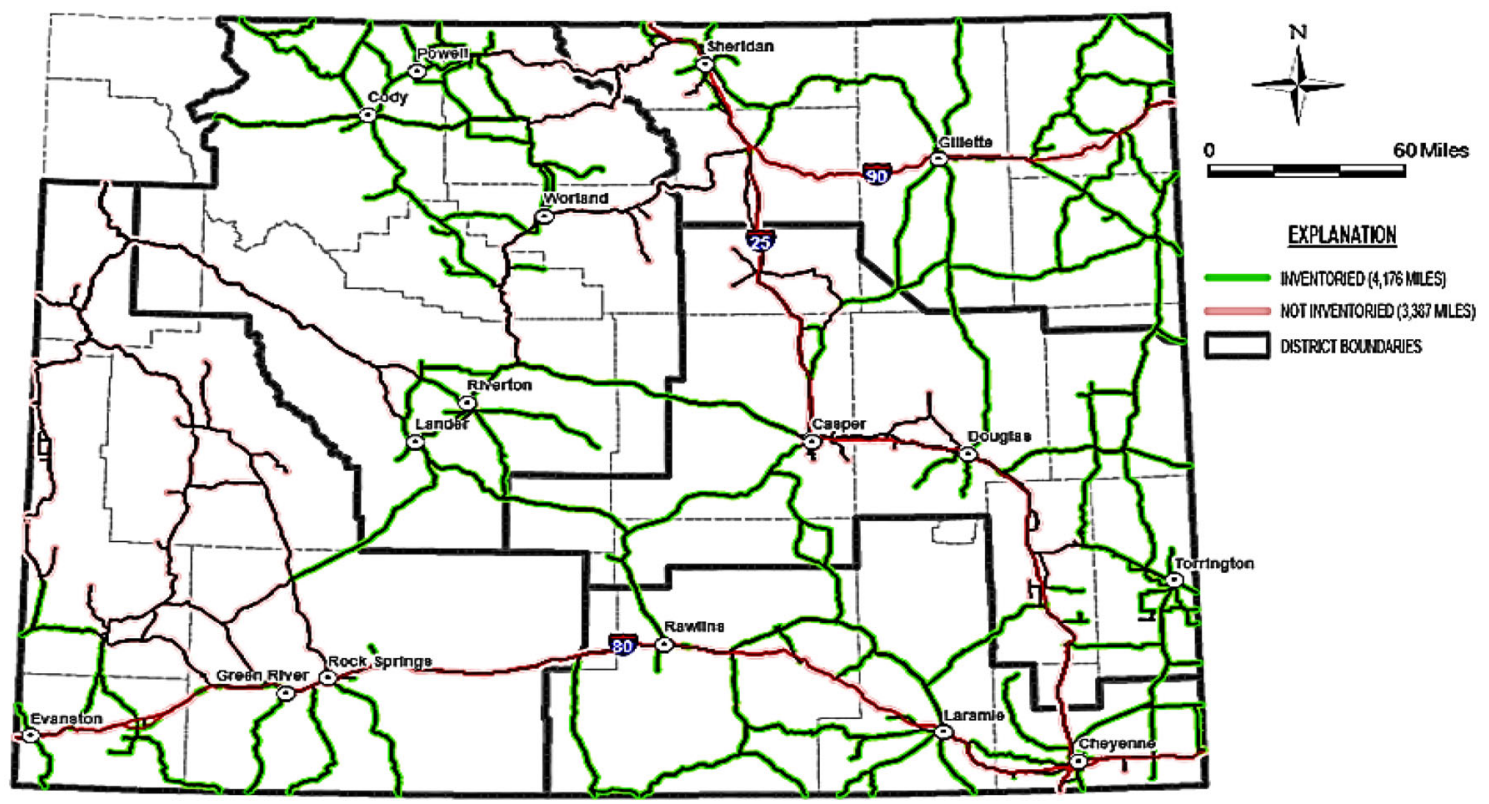

Fig. 1 Roads with traffic barrier inventoried in this study

categories were defined for crash severity as dependent variables. The discrete categories were developed using the following $\mathrm{KABCO}$ injury scale; however, the crash types $\mathrm{K}$ and $\mathrm{A}$, and types $\mathrm{B}$ and $\mathrm{C}$ were combined to provide an acceptable data frequency for all the categories.

KABCO injury scale developed by the National Safety Council [30]:

- Type K: the crashes result in fatal injury

- Type A: the crashes result in incapacitating injury

- Type B: the crashes result in non-incapacitating injury

- Type C: the crashes result in possible injury

- Type O: the crashes result in no injury (property damage only)

Therefore, crash severity categories were considered in this study as below:

- High-severity crashes (types $\mathrm{K}$ and $\mathrm{A}$ )

- Moderate-severity crashes (types B and C)

- Low-severity crashes (type O)

The Statistical Analysis System (SAS) package was also selected as the tool for conducting the ordered logistic regression. Wald-based Chi-square was done with the help of the logistic process in SAS at a significant level of 0.10 for entering the analytical model and a 0.05 level for staying in the model.

\subsection{Data description}

Table 1 shows the description of dependent and significant independent variables in the analysis. Overall, 15 independent variables were found effective on the severity of crashes involving traffic barriers and end treatments. Vehicles were divided into six groups based on differences in terms of size, weight, and dynamic features. Surface condition categories are representing the possible conditions in Wyoming. These categories are also consistent with the ones chosen by Russo and Savolainen [27]. Four types of barriers, i.e., concrete, W-beam, box beam, and cable barriers had been collected during the field survey; however, cable barriers were not entered in the analysis due to the low frequency. Overall, there were 19 cable barrier segments which were involved only in six crashes. The traffic barriers included in the study are illustrated in Fig. 2.

The traffic barriers with a height between 28 and $31 \mathrm{in}$. and more than $31 \mathrm{in}$. were compared to the traffic barriers which had less than 28 in. height. These categories were selected according to the results published in RDG [9] and NCHRP project no. 350 [11]. Side slope height and offset were divided into three and four groups, respectively, to include a precise evaluation regarding their effects on crash severity. The rest of the independent variables were considered as binary either due to having only two choices (road class, rollover, driver gender, driver improper restraint, and alcohol involved) or because of providing a reasonable balance between frequency of the different categories (shoulder width, end treatment type, and the offset). Figure 3 shows a cross-section plot to make a clearer view of these traffic barrier variables. 
Table 1 Description of response and significant independent variables in the analysis

\begin{tabular}{|c|c|c|c|}
\hline Variable & Variable description & $\begin{array}{l}\text { Variable } \\
\text { type }\end{array}$ & Categories \\
\hline \multicolumn{4}{|l|}{ Response } \\
\hline $\begin{array}{l}\text { Crash } \\
\text { severity }\end{array}$ & The severity of crashes involving traffic barriers & Categorical & $\begin{array}{l}\text { Fatal/incapacitating } \\
\text { injury } \\
\text { Non- } \\
\text { incapacitating/possible } \\
\text { injury } \\
\text { Property damage only } \\
\text { (PDO) }\end{array}$ \\
\hline \multicolumn{4}{|c|}{ Environmental } \\
\hline $\begin{array}{l}\text { Vehicle } \\
\text { type }\end{array}$ & An indicator of the type of vehicle involved in crashes & Categorical & $\begin{array}{l}\text { Passenger car } \\
\text { SUV } \\
\text { Pickup } \\
\text { Truck } \\
\text { Motorcycle } \\
\text { Other }\end{array}$ \\
\hline $\begin{array}{l}\text { Surface } \\
\text { condition }\end{array}$ & An indicator of roadway surface condition at the time of a crash & Categorical & $\begin{array}{l}\text { Dry } \\
\text { Wet } \\
\text { Snow } \\
\text { Ice } \\
\text { Other }\end{array}$ \\
\hline $\begin{array}{l}\text { Shoulder } \\
\text { width }\end{array}$ & An indicator of the shoulder width at the site & Binary & $\begin{array}{l}\leq 6 \mathrm{ft} \\
>6 \mathrm{ft}\end{array}$ \\
\hline $\begin{array}{c}\text { Road } \\
\text { class }\end{array}$ & An indicator of the road functional class of the site that a crash occurred & Binary & $\begin{array}{l}\text { Urban } \\
\text { Rural }\end{array}$ \\
\hline Rollover & Indicator whether a rollover occurred in the crash & Binary & $\begin{array}{l}\text { Yes } \\
\text { No }\end{array}$ \\
\hline \multicolumn{4}{|l|}{ Driver } \\
\hline Gender & An indicator of the gender of the driver involved in the crash & Binary & $\begin{array}{l}\text { Female } \\
\text { Male }\end{array}$ \\
\hline $\begin{array}{l}\text { Improper } \\
\text { restraint }\end{array}$ & Indicator whether the driver had improper restraint in the crash & Binary & $\begin{array}{l}\text { Yes } \\
\text { No }\end{array}$ \\
\hline $\begin{array}{l}\text { Alcohol } \\
\text { involved }\end{array}$ & Indicator whether the driver used alcohol and drug & Binary & $\begin{array}{l}\text { Yes } \\
\text { No }\end{array}$ \\
\hline \multicolumn{4}{|c|}{ Traffic barrier } \\
\hline Type & An indicator of the traffic barrier type involved in the crash & Categorical & $\begin{array}{l}\text { Concrete } \\
\text { W-beam } \\
\text { Box beam }\end{array}$ \\
\hline $\begin{array}{l}\text { System } \\
\text { height }\end{array}$ & $\begin{array}{l}\text { An indicator of the vertical measurement from the ground to the top of the traffic barrier } \\
\text { involved in the crash }\end{array}$ & Categorical & $\begin{array}{l}\leq 28 \text { in. } \\
28 \text { in. }<\text { Height } \leq 31 \text { in. } \\
\text { Height }>31 \text { in. }\end{array}$ \\
\hline $\begin{array}{l}\text { Side slope } \\
\text { height }\end{array}$ & $\begin{array}{l}\text { An indicator of the vertical measurement from the surface at the beginning of the taper } \\
\text { to the face of the traffic barrier involved in the crash }\end{array}$ & Categorical & $\begin{array}{l}\text { Flat or higher than } \\
\quad \text { surface } \\
0 \text { (Flat) }<\text { Height } \leq 1 \mathrm{ft} \\
\text { Height }>1 \mathrm{ft}\end{array}$ \\
\hline $\begin{array}{l}\text { Post- } \\
\text { spacing }\end{array}$ & $\begin{array}{l}\text { An indicator of the distance between the posts in the main tangent run of the traffic } \\
\text { barrier involved in the crash }\end{array}$ & Categorical & $\begin{array}{l}\leq 5.5 \mathrm{ft} \\
5.5 \mathrm{ft}<\text { Spacing } \leq 6 \mathrm{ft} \\
6 \mathrm{ft}<\text { Spacing } \leq 6.5 \mathrm{ft} \\
>6.5 \mathrm{ft}\end{array}$ \\
\hline
\end{tabular}


Table 1 continued

\begin{tabular}{|c|c|c|c|}
\hline Variable & Variable description & $\begin{array}{l}\text { Variable } \\
\text { type }\end{array}$ & Categories \\
\hline $\begin{array}{r}\text { System } \\
\text { height }\end{array}$ & $\begin{array}{l}\text { An indicator of the vertical measurement from the ground to the top of the end terminal } \\
\text { involved in the crash }\end{array}$ & Categorical & $\begin{array}{l}\leq 28 \text { in. } \\
28 \text { in. }<\text { Height } \leq 31 \text { in. } \\
\text { Height }>31 \text { in. }\end{array}$ \\
\hline Type & Indicator whether a flare or parallel end treatment was involved in the crash & Binary & $\begin{array}{l}\text { Parallel } \\
\text { Flare }\end{array}$ \\
\hline Offset & $\begin{array}{l}\text { An indicator of the horizontal distance from the surface taper to the face of the end } \\
\text { treatment involved in the crash }\end{array}$ & Binary & $\begin{array}{l}\leq 2 \mathrm{ft} \\
>2 \mathrm{ft}\end{array}$ \\
\hline
\end{tabular}
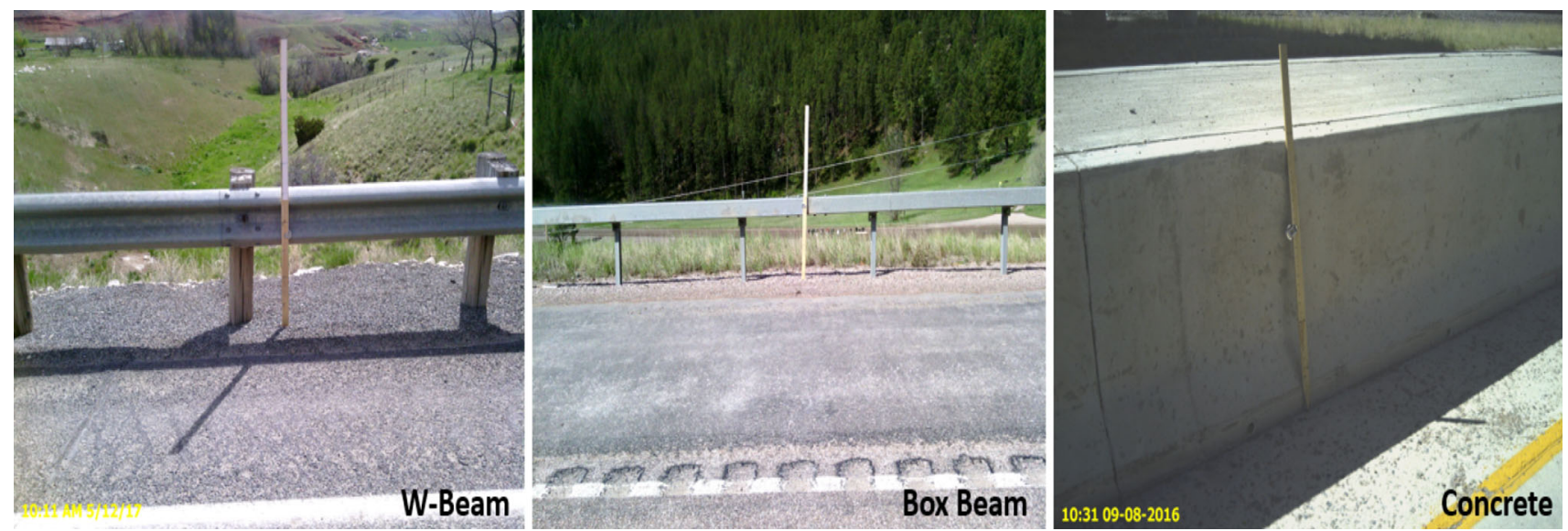

Fig. 2 Traffic barrier types considered in the analysis

All traffic barrier variables were measured in five locations for the flare traffic barriers and three locations for the parallel barriers. Note that a traffic barrier called flared when it is not parallel to the edge of the roadway [9]. The beginning, middle, and the endpoint of the parallel traffic barriers were inventoried, while the beginning and the end of the tangent (where the traffic barrier comes up tangent with the roadway) were also recorded in the flare barriers. The average of the measurements was mostly considered in the analysis; however, in some of the rare cases with the considerable differences between measurements, the photographs were reviewed to consider the value that represents the dimension accurately.

\section{Discussion}

In summary, Wyoming non-interstate roads had 1862 crashes involving traffic barriers between 2007 and 2017. A total of 308 of the crashes were either multi-vehicle crashes or related to work zone areas (with temporary traffic barriers). These crashes were removed since the severity might not be as a direct influence of hitting traffic barriers. Also,
724 of the crashes occurred on the roads which the traffic barrier dimensions were not inventoried during the field survey. Therefore, excluding the six crashes involved with cable barriers, the analysis was conducted including 826 crashes in this study. The following paragraphs elaborate on the models and findings found in the analysis.

\subsection{Modeling crashes involving traffic barriers}

Table 2 presents the outcomes extracted from the analysis of crashes involving traffic barriers, while the statistics of variables are provided in Table 3. An odds ratio (OR) less than one shows a reduction in crash severity in comparison with the reference category, while the crash severity is predicted to be higher if the OR is more than one.

Among the traffic barrier variables, type, system height, side slope height, and post-spacing were found effective on crash severity. Both the W-beam and box beam barriers had lower OR in comparison with concrete barriers; however, only the performance of the box beam barriers was found significantly different compared to concrete barriers. It was estimated that the traffic barriers with a height between 28 and 31 in. resulted in less severe crashes. On 


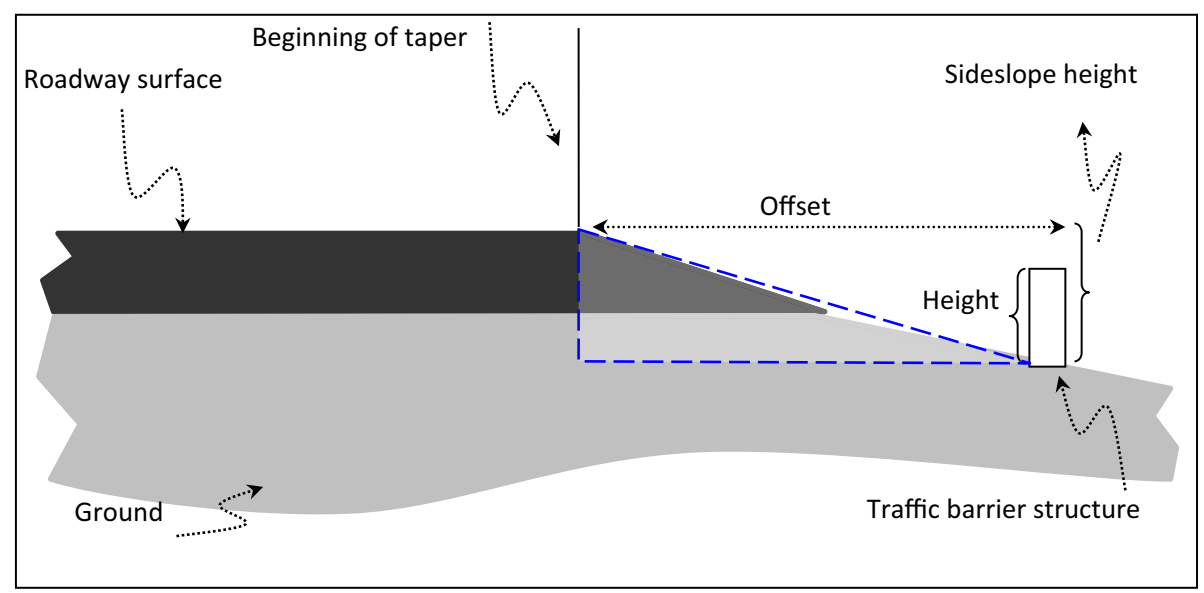

Fig. 3 A crosscut view of roadways with a side traffic barrier

Table 2 Ordered logistic regression for severity of crashes involving traffic barriers

\begin{tabular}{|c|c|c|c|c|c|c|c|}
\hline Variable & Categories & Reference category & Estimates & Standard error & Wald $\chi^{2}$ & $P$ value & Odds ratio \\
\hline Intercept 2 & - & - & -4.138 & 0.8056 & 26.387 & $<.0001$ & - \\
\hline Intercept 1 & - & - & -1.244 & 0.7667 & 2.635 & 0.1045 & - \\
\hline \multicolumn{8}{|l|}{ Environmental } \\
\hline \multirow[t]{5}{*}{ Vehicle type } & SUV & Passenger car & -0.239 & 0.2901 & 0.682 & 0.4086 & 0.787 \\
\hline & Pickup & Passenger car & 0.151 & 0.2366 & 0.410 & 0.5219 & 1.164 \\
\hline & Truck & Passenger car & -0.467 & 0.6183 & 0.572 & 0.4494 & 0.626 \\
\hline & Motorcycle & Passenger car & 5.023 & 0.5161 & 94.725 & $<.0001$ & 151.86 \\
\hline & Other & Passenger car & 0.219 & 0.4795 & 0.209 & 0.6474 & 1.245 \\
\hline \multirow[t]{4}{*}{ Surface condition } & Wet & Dry & -0.059 & 0.3481 & 0.028 & 0.8650 & 0.943 \\
\hline & Snow & Dry & -1.074 & 0.3407 & 9.935 & $<.0001$ & 0.342 \\
\hline & Ice & Dry & -1.019 & 0.2498 & 16.649 & $<.0001$ & 0.361 \\
\hline & Other (slush, sand) & Dry & -0.574 & 0.4340 & 1.753 & 0.1854 & 0.563 \\
\hline Rollover & Yes & No & 2.094 & 0.3173 & 43.562 & $<.0001$ & 8.119 \\
\hline Road class & Rural & Urban & 0.546 & 0.2288 & 5.699 & 0.0170 & 1.727 \\
\hline \multicolumn{8}{|l|}{ Driver } \\
\hline Gender & Female & Male & 0.815 & 0.2103 & 15.043 & $<.0001$ & 2.261 \\
\hline Improper restraint & Yes & No & 1.064 & 0.2476 & 18.463 & $<.0001$ & 2.898 \\
\hline Alcohol involved & Yes & No & 0.791 & 0.2671 & 8.789 & $<.0001$ & 2.208 \\
\hline \multicolumn{8}{|l|}{ Traffic barrier } \\
\hline \multirow[t]{2}{*}{ Type } & W-beam & Concrete & -0.231 & 0.4377 & 0.280 & 0.5966 & 0.793 \\
\hline & Box beam & Concrete & -0.301 & 0.6982 & 0.186 & 0.0481 & 0.740 \\
\hline \multirow[t]{2}{*}{ System height } & 28 in. $<$ Height $\leq 31$ in. & $\leq 28$ in. & -0.350 & 0.2129 & 2.713 & 0.0395 & 0.704 \\
\hline & Height $>31$ in. & $\leq 28$ in. & 0.029 & 0.3371 & 0.007 & 0.9293 & 1.030 \\
\hline \multirow[t]{2}{*}{ Sideslope height } & 0 (Flat) $<$ Height $\leq 1 \mathrm{ft}$ & Flat or Higher than Surface & 0.246 & 0.2248 & 1.203 & 0.1727 & 1.280 \\
\hline & Height $>1 \mathrm{ft}$ & Flat or Higher than Surface & 0.559 & 0.3496 & 2.560 & 0.0306 & 1.750 \\
\hline \multirow[t]{3}{*}{ Post-spacing } & $5.5 \mathrm{ft}<$ Spacing $\leq 6 \mathrm{ft}$ & $\leq 5.5 \mathrm{ft}$ & -0.118 & 0.4158 & 0.081 & 0.7758 & 0.888 \\
\hline & $6 \mathrm{ft}<$ Spacing $\leq 6.5 \mathrm{ft}$ & $\leq 5.5 \mathrm{ft}$ & -0.8141 & 0.4414 & 3.4012 & 0.0451 & 0.443 \\
\hline & $>6.5 \mathrm{ft}$ & $\leq 5.5 \mathrm{ft}$ & -2.1312 & 1.1354 & 3.5232 & 0.0605 & 0.119 \\
\hline
\end{tabular}

Bold represents the insignificant variables in the level of 0.05 
Table 3 Statistics of dependent and significant independent variables for crashes involving traffic barriers

\begin{tabular}{|c|c|c|c|}
\hline Variable type & Categories & Frequency & Percent \\
\hline \multicolumn{4}{|l|}{ Response } \\
\hline \multirow[t]{3}{*}{ Crash severity } & Fatal/incapacitating injury & 45 & 6 \\
\hline & $\begin{array}{l}\text { Non-incapacitating/possible } \\
\text { injury }\end{array}$ & 167 & 20 \\
\hline & $\begin{array}{l}\text { Property damage only } \\
\text { (PDO) }\end{array}$ & 614 & 74 \\
\hline \multicolumn{4}{|l|}{ Environmental } \\
\hline \multirow[t]{6}{*}{ Vehicle type } & Passenger car & 346 & 42 \\
\hline & SUV & 137 & 17 \\
\hline & Pickup & 239 & 29 \\
\hline & Truck & 34 & 4 \\
\hline & Motorcycle & 34 & 4 \\
\hline & Other & 36 & 4 \\
\hline \multirow{5}{*}{$\begin{array}{l}\text { Surface } \\
\text { condition }\end{array}$} & Dry & 341 & 41 \\
\hline & Wet & 59 & 7 \\
\hline & Snow & 107 & 13 \\
\hline & Ice & 272 & 33 \\
\hline & Other & 47 & 6 \\
\hline \multirow[t]{2}{*}{ Road class } & Urban & 278 & 34 \\
\hline & Rural & 548 & 66 \\
\hline \multirow[t]{2}{*}{ Rollover } & Yes & 55 & 7 \\
\hline & No & 771 & 93 \\
\hline \multicolumn{4}{|l|}{ Driver } \\
\hline \multirow[t]{2}{*}{ Gender } & Female & 314 & 38 \\
\hline & Male & 512 & 62 \\
\hline \multirow{2}{*}{$\begin{array}{l}\text { Improper } \\
\text { restraint }\end{array}$} & Yes & 104 & 13 \\
\hline & No & 722 & 87 \\
\hline \multirow{2}{*}{$\begin{array}{l}\text { Alcohol } \\
\text { involved }\end{array}$} & Yes & 98 & 12 \\
\hline & No & 729 & 88 \\
\hline \multicolumn{4}{|l|}{ Traffic barrier } \\
\hline \multirow[t]{3}{*}{ Type } & Concrete & 44 & 6 \\
\hline & W-beam & 367 & 44 \\
\hline & Box beam & 416 & 50 \\
\hline \multirow[t]{3}{*}{ System height } & $\leq 28$ in. & 244 & 30 \\
\hline & 28 in. $<$ Height $\leq 31$ in. & 477 & 57 \\
\hline & Height $>31$ in. & 105 & 13 \\
\hline \multirow{3}{*}{$\begin{array}{l}\text { Side slope } \\
\text { height }\end{array}$} & Flat or higher than surface & 285 & 35 \\
\hline & 0 (Flat) $<$ Height $\leq 1 \mathrm{ft}$ & 466 & 56 \\
\hline & Height $>1 \mathrm{ft}$ & 75 & 9 \\
\hline \multirow[t]{4}{*}{ Post-spacing } & $\leq 5.5 \mathrm{ft}$ & 47 & 6 \\
\hline & $5.5 \mathrm{ft}<$ Spacing $\leq 6$ in. & 304 & 38 \\
\hline & $6 \mathrm{ft}<$ Spacing $\leq 6.5$ in. & 427 & 53 \\
\hline & $>6.5 \mathrm{ft}$ & 20 & 3 \\
\hline
\end{tabular}

the other hand, the performance of the traffic barriers was identified almost the same (with an OR of 1.03 and a $P$ value of 0.92 ) either when the height is lower than $28 \mathrm{in}$. or higher than $31 \mathrm{in.}$ Figure 4 also indicates the ratio of high-severity crashes to all crashes. As shown in Fig. 4, less than $3 \%$ of the crashes involving traffic barriers with a height of $31 \mathrm{in}$. were high-severity, while the percentage reached to about $8 \%$ when the traffic barrier height was shorter than $29 \mathrm{in}$. or higher than $32 \mathrm{in}$. This fact is consistent with past findings. The short traffic barriers increase the potential of vehicle override crashes, while the tall traffic barriers could also cause an underride crash [31]. The risk of an override crash would be probably higher for the trucks and heavy vehicles with a higher center of gravity (CG). Therefore, the regions like Rocky Mountain are at higher risk of override crashes due to their considerable truck traffic. According to FHWA's W-Beam Guardrail Repair [32], the guardrails with the height shorter than 24 in. were identified as "no longer reasonably functional." Based on Wiebelhaus et al. [4], the traffic barriers with a height between 27 and 30 in. could minimize the risk of override and underride and lead to a redirection.

High-severity crashes were more likely to occur on the downgrade side slopes with a vertical difference of over one foot between traffic barrier and the road surface. This should be due to the suspension reactions that could happen in sharp side slopes. According to RDG (AASHTO 2011), the bumper path of ROR vehicles would not follow a constant line on sharp side slopes, and the height of the bumper is deviating in every moment on the side slope. For example, based on bumper trajectory data presented in RDG (AASHTO 2011), the bumper path could be $8.8 \mathrm{in}$. higher than the normal height on a $1 \mathrm{~V}: 2 \mathrm{H}$ side slope with an encroachment angle of $15^{\circ}$. Regarding post-spacing, crash severity could be reduced by about $56 \%$ when the posts were located with a spacing between 6 and $6.5 \mathrm{ft}$ in comparison with the post-spacing shorter than $5.5 \mathrm{ft}$. Note that a $6.3 \mathrm{ft}$ post-spacing is also recommended by RDG (AASHTO 2011) for W-beam guardrails.

From the viewpoint of road environmental variables, the rollover significantly increased the severity of crashes involving traffic barriers with an OR more than eight. The rural roadways were found more dangerous than the urban roadways. The probability of high-severity crashes was examined about $72 \%$ higher on the rural roadways. The similar results as the studies by Molan et al. [33], Zou et al. [26] and Russo and Savolainen [27] were found regarding the vehicle type and the surface condition in this study. Motorcycles were significantly vulnerable to crashes involving traffic barriers. Icy and snowy surface conditions could reduce the crash severity because drivers are probably driving slower and more cautious at adverse weather conditions.

As could be predicted, the effect of alcohol use and driver improper restraint were found significant in causing higher severity in crashes involving traffic barriers. Female 


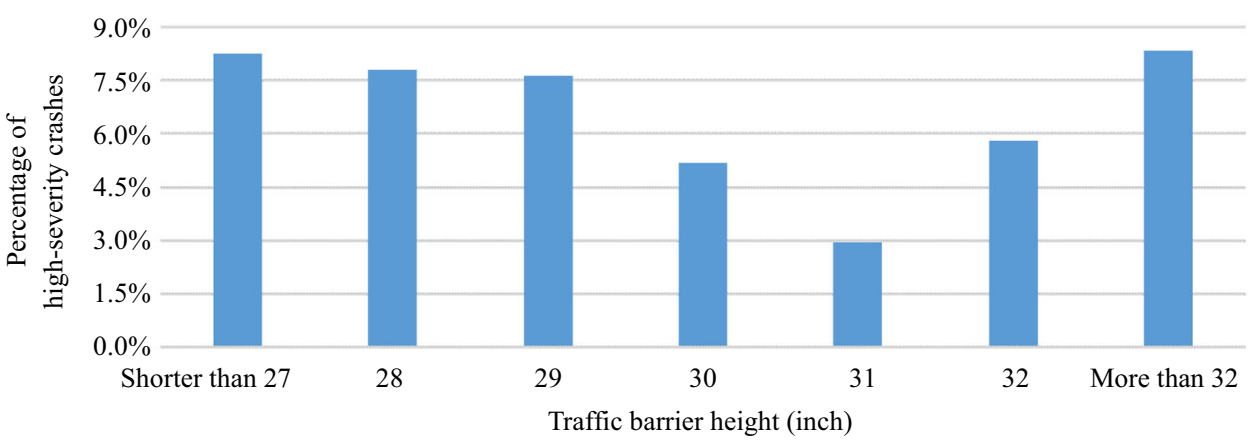

Fig. 4 Percentage of high-severity crashes in various categories of traffic barrier height

Table 4 Ordered logistic regression for severity of crashes involving end treatments

\begin{tabular}{lllrrrrr}
\hline Variable & Categories & Reference category & Estimates & Standard error & Wald $\chi^{2}$ & $P$ value & Odds ratio \\
\hline Intercept 2 & - & - & -2.2424 & 0.9955 & 5.074 & 0.0243 & - \\
Intercept 1 & - & - & 0.9240 & 1.0056 & 0.844 & 0.3582 & - \\
Environment & & & & & & \\
Surface condition & Wet & Dry & 0.7927 & 0.8963 & 0.782 & $\mathbf{0 . 3 7 6 4}$ & 2.209 \\
& Snow & Dry & -0.2162 & 0.7809 & 0.076 & $\mathbf{0 . 7 8 1 9}$ & 0.806 \\
& Ice & Dry & -2.4396 & 0.9423 & 6.702 & 0.0096 & 0.087 \\
& Other (slush, sand) & Dry & -13.3249 & 510.8 & 0.000 & $\mathbf{0 . 9 7 9 2}$ & $<0.001$ \\
Rollover & Yes & No & 2.9785 & 0.7354 & 16.402 & $<.0001$ & 19.657 \\
Shoulder width & $>6 \mathrm{ft}$ & $\leq 6 \mathrm{ft}$ & 1.4947 & 0.5883 & 6.454 & $<.0001$ & 4.458 \\
Driver Improper restraint & Yes & No & 1.2502 & 0.5829 & 4.599 & $<.0001$ & 3.491 \\
End treatments & & & & & & \\
System height & 28 in. $<$ Height $\leq 31$ in. & $\leq 28$ in. & -1.1837 & 0.6117 & 3.744 & 0.0330 & 0.306 \\
& Height $>31$ in. & $\leq 28$ in. & -0.9139 & 0.9311 & 0.963 & $\mathbf{0 . 3 2 6 3}$ & 0.401 \\
Type & Flare & Parallel & 0.8398 & 0.5125 & 2.684 & $\mathbf{0 . 0 7 1 3}$ & 2.316 \\
Offset & $>2 \mathrm{ft}$ & $\leq 2 \mathrm{ft}$ & 1.3437 & 0.6537 & 4.224 & 0.0398 & 3.833 \\
\hline
\end{tabular}

Bold represents the insignificant variables in the level of 0.05

drivers were involved in fewer crashes in comparison with male drivers; however, they experienced higher crash severity.

\subsection{Modeling crashes involving end treatments}

To find the differences between the crashes hitting traffic barrier faces in comparison with the cases when vehicles hit the end treatment, another model was presented considering only the end treatment crashes. Reviewing the crash data, there were 110 crashes involving the end treatments. Table 4 shows the variables affecting the severity of end treatment crashes. The statistics of the variable categories are also provided in Table 5.

Similar to the results presented in Table 3, the traffic barriers with a height range of $28-31$ in. were found as the safest category in end treatment crashes. The higher traffic barriers ( $>31$ in.) should also be safer than the traffic barriers shorter than $28 \mathrm{in}$.; however, the difference was evaluated insignificant at the level of 0.05 . As another variable related to the end treatment dimensions, offset (from the surface taper to the end treatment) would significantly affect the crash severity. The further offsets $(>2 \mathrm{ft}$ ) were evaluated more dangerous than the shorter offsets showing an OR of 3.83. Paying attention to the higher severity estimated in the wide shoulders ( $>6 \mathrm{ft}$ ), it can be concluded that the crash severity increases as the end treatment is located further away from the traffic lane. Designers usually try to consider a wide offset in design to reduce the probability of traffic barrier crashes. However, based on Table 4, this fact seems unsafe in terms of severity of crashes involving end treatments. The crashes hitting flare end treatments were also found about 2.3 times more severe than the crashes with parallel end treatments. 
Table 5 Statistics of dependent and significant independent variables for crashes involving end treatments

\begin{tabular}{|c|c|c|c|}
\hline Variable type & Categories & Frequency & Percent \\
\hline \multicolumn{4}{|l|}{ Response } \\
\hline \multirow[t]{3}{*}{ Crash severity } & Fatal/incapacitating injury & 6 & 6 \\
\hline & $\begin{array}{l}\text { Non- } \\
\text { incapacitating/possible } \\
\text { injury }\end{array}$ & 28 & 25 \\
\hline & $\begin{array}{l}\text { Property damage only } \\
\text { (PDO) }\end{array}$ & 76 & 69 \\
\hline \multicolumn{4}{|l|}{ Environmental } \\
\hline \multirow{5}{*}{$\begin{array}{l}\text { Surface } \\
\text { conditions }\end{array}$} & Dry & 63 & 57 \\
\hline & Wet & 9 & 8 \\
\hline & Snow & 12 & 11 \\
\hline & Ice & 20 & 18 \\
\hline & Other & 6 & 6 \\
\hline \multirow[t]{2}{*}{ Rollover } & Yes & 14 & 13 \\
\hline & No & 96 & 87 \\
\hline \multirow{2}{*}{$\begin{array}{l}\text { Shoulder } \\
\text { width }\end{array}$} & $\leq 6 \mathrm{ft}$ & 50 & 45 \\
\hline & $>6 \mathrm{ft}$ & 60 & 55 \\
\hline \multicolumn{4}{|l|}{ Driver } \\
\hline \multirow{2}{*}{$\begin{array}{l}\text { Improper } \\
\text { restraint }\end{array}$} & Yes & 20 & 18 \\
\hline & No & 90 & 82 \\
\hline \multicolumn{4}{|l|}{ End treatments } \\
\hline \multirow[t]{3}{*}{ System height } & $\leq 28 \mathrm{in}$ & 49 & 44 \\
\hline & 28 in. $<$ Height $\leq 31$ in. & 47 & 43 \\
\hline & Height $>31$ in. & 14 & 13 \\
\hline \multirow[t]{2}{*}{ Type } & Flare & 48 & 44 \\
\hline & Parallel & 62 & 56 \\
\hline \multirow[t]{2}{*}{ Offset } & $\leq 2 \mathrm{ft}$ & 43 & 39 \\
\hline & $>2 \mathrm{ft}$ & 67 & 61 \\
\hline
\end{tabular}

The same as a previous study [25], the rollover and the driver improper restraint significantly affected the crash severity. The unbelted drivers experienced higher crash severity compared to the belted drivers. The OR of 3.49 shows that using seatbelt could be more efficient in reducing the severity of end treatment crashes than the crashes hitting the face of the traffic barrier (OR 2.89). Rollover would also extremely increase the severity of end treatment crashes. The OR of end treatment crashes involving rollover was found about 19.65. Note that an OR equal to 8.11 is examined in Table 2 regarding the threat of rollover when a vehicle hits the traffic barrier face. Regarding surface conditions, only the icy surfaces could significantly reduce the severity of crashes involving end treatment.

\section{Conclusions}

This research modeled the severity of crashes involving traffic barriers and end treatments. Dimension and geometric data of over 1.3 million linear feet of traffic barriers (approximately 4,176 miles of non-interstate roadways) were measured in a field survey conducted from June 2016 to September 2017 in Wyoming. Also, crashes reported between 2007 and 2017 were collected to provide a comprehensive database for the analysis. The following paragraphs point out some of the important results of this research.

Box beam barriers were found safer than the other traffic barriers considered in this study. There was no significant difference (at the level of 0.05) between the performances of the W-beam and the concrete barriers in terms of crash severity.

The traffic barriers and end treatments that had a height between 28 and 31 in. resulted in less severe crashes in comparison with the crashes involving shorter system height. Only $3 \%$ of the vehicles hitting a 31-inch-high traffic barrier experienced high-severity (fatal and incapacitating) injuries, while the percentage reached to about $8 \%$ when the traffic barrier height was shorter than 28 in., or taller than 32 in.

The downgrade side slopes with a vertical distance from the surface to the traffic barrier more than one foot pose a safety threat (with an odds ratio of 1.75) in comparison with flat side slopes. Also, the traffic barrier crashes were significantly less severe when there was a post-spacing of $6-6.5 \mathrm{ft}$.

The flared end treatments are more likely to cause higher severity than the parallel end treatments. Also, the analysis concluded that the high-severity crashes are more likely when the end treatment is located further from the traffic lane.

Rollover crashes and unbelted drivers significantly affected the severity of crashes hitting either face or end treatment of the traffic barriers; however, the OR values were examined higher in the end treatment crashes. Rollover increases severity of end treatment crashes causing an OR equal to 19.65 , while an 8.11-OR was examined for the effect of the rollover on crashes when a vehicle hits the traffic barrier face.

This study included all different classes of roadways (state, FAP, FAS, and FAU) except interstates. Future studies are recommended to investigate the variables affecting traffic barrier crashes on interstate roads. The current analysis could not include the cable barriers in the analysis due to their low frequency on non-interstate roads, while they are widespread on interstate roads. 
Acknowledgements The authors would like to acknowledge that this work is part of project \#RS03218 funded by the Wyoming Department of Transportation (WYDOT). The subject matter, all figures, tables, and equations not previously copyrighted by outside sources are copyrighted by WYDOT, State of Wyoming and the University of Wyoming. All rights reserved copy righted in 2016. The authors are also grateful of Trihydro Corporation for collecting the statewide traffic barrier data as the title of WYDOT guardrail inventory project no. HPR1217.

Open Access This article is distributed under the terms of the Creative Commons Attribution 4.0 International License (http:// creativecommons.org/licenses/by/4.0/), which permits unrestricted use, distribution, and reproduction in any medium, provided you give appropriate credit to the original author(s) and the source, provide a link to the Creative Commons license, and indicate if changes were made.

\section{References}

1. National Highway Traffic Safety Administration (2016) Motor vehicle traffic crashes as a leading cause of death in the United States, 2012-2014. U.S. Department of Transportation

2. Federal Highway Administration (2009) Highway safety improvement program manual, federal highway administration, Report No. FHWA-SA-09-029

3. Federal Highway Administration (2017) Roadway departure safety. Washington DC. https://safety.fhwa.dot.gov/roadway_ dept/

4. Wiebelhaus M, Lechtenberg K, Sicking D, Faller D, Rosenbaugh S (2013) Cost effective treatment of existing guardrail systems. MwRSF Research Report No. TRP03-254-13

5. Mehrara Molan A, Rezapour M, Ksaibati K (2019) Modeling the impact of various variables on severity of crashes involving traffic barriers. J Transp Saf Secur. https://doi.org/10.1080/ 19439962.2018 .1547995

6. Nixon Approves Limit of 55 MPH (1974) The New York Times. January 3, 1974. pp 1, 24

7. Retting R, Teoh E (2008) Traffic speeds on interstates and freeways 10 years after repeal of national maximum speed limit. Traffic Inj Prev 9(2):119-124

8. The Statistics Portal (2018). https://www.statista.com/statistics/ 746742/number-of-new-pickup-sales-in-the-united-states/

9. American Association of State Highway and Transportation Officials (2011) Roadside design guide

10. National Highway Traffic Administration (2012) A compilation of motor vehicle crash data from the fatality analysis reporting system and the general estimates system. U.S. Department of Transportation

11. National Cooperative Highway Research Program (1993) Recommended procedures for the safety performance evaluation of highway features. NCHRP Report 350, Washington DC

12. Mehrara Molan A, Ksaibati K (2018) Developing the New Barrier Condition Index (BCI) to unify the barrier assessments-a case study in wind river indian reservation, Wyoming. Open Transp J, Bentham Open 12(1):182-191. https://doi.org/10.2174/ 1874447801812010182

13. Julin R, Pajouh M, Stolle C, Reid J (2017) Maximum mounting height for Midwest Guardrail system (MGS). In: 96th Annual meeting of TRB, Washington DC
14. Seckinger R, Roschke P, Stolle C, Abu-Odeh A, Bligh R (2017) Numerical simulation of mow strip subcomponents used with strong post Guardrail systems. Int $\mathrm{J}$ Crashworthiness 10(4):419-427

15. Schmidt J, Weiland N, Reid J, Faller R (2015) Minimum effective length for the Midwest Guardrail system. In: 94th Annual meeting of TRB, Washington DC

16. Albuquerque F, Stolle C, Sicking D, Faller R, Lechtenberg K, Emerson E (2015) Optimization of Guardrail length-of-need for interstate highways. In: 94th Annual meeting of TRB, Washington DC

17. Hampton C, Gabler H (2013) Development of a missing post repair guideline for longitudinal barrier crash safety. J Transp Eng 139:6

18. Tan K, Tan W, Wong S (2008) Design of motorcyclist-friendly guardrail using finite element analysis. Int $\mathbf{J}$ Crashworthiness 13(5):567-577

19. Federal Highway Administration (2008) W-beam Guardrail repair. A guide for highway and street maintenance personnel

20. Cafiso S, Agostino C, Persaud B (2017) Investigating the influence on safety of retrofitting Italian motorways with barriers meeting a new EU standard. Traffic Injur Prev 18(3)

21. Villwock M, Blond N, Tarko A (2009) Cable barriers and traffic safety on rural interstates. J Transp Eng 137(4)

22. Chimba D, Ruhazwe E, Allen S, Waters J (2017) Digesting the safety effectiveness of cable barrier systems by numbers. J Transp Res Part A 95:227-237

23. Park J, Abdel-Aty M, Lee J (2010) Use of empirical and full Bayes before-after approaches to estimate the safety effects of roadside barriers with different crash conditions. J Saf Res 58(2016):31-40

24. Holdridge J, Shankar V, Ulfarsson G (2005) The crash severity impacts of fixed roadside objects. J Saf Res 36(2)

25. Johnson N, Gabler H (2015) Injury outcome in crashes with Guardrail end terminals. Traffic Inj Prev 16

26. Zou Y, Tarko AP, Chen E, Romero MA (2014) Effectiveness of cable barriers, Guardrails, and concrete barrier walls in reducing the risk of injury. J Accid Anal Prev 72:55-65

27. Russo B, Savolainen P (2018) A comparison of freeway median crash frequency, severity, and barrier strike outcomes by median barrier type. J Accid Anal Prev 117(2018):216-224

28. Wyoming Department of Transportation (2017) WYDOT Guardrail inventory-2016-2017 field season summary, Project No. HPR1216-Statewide. Wyoming Department of Transportation

29. Li N, Park B, Lambert J (2017) Effect of guardrail on reducing fatal and severe injuries on freeways: real-world crash data analysis and performance assessment. J Transp Saf Secur, Taylor \& Francis

30. National Safety Council (1970) Manual on classification of motor vehicle traffic accidents. Chicago, USA

31. Julin R, Pajouh M, Stolle C, Reid J Maximum mounting height for Midwest Guardrail system (MGS). In: 96th Annual meeting of TRB. Washington DC

32. Federal Highway Administration (2008) W-beam Guardrail repair. A guide for highway and street maintenance personnel

33. Mehrara Molan A, Rezapour M, Ksaibati K (2019) Investigating the relationship between the type of traffic barrier and crash severity in trucks and light vehicles. J Traffic Transp Eng (in press) 